University of Michigan Law School

University of Michigan Law School Scholarship Repository

Law \& Economics Working Papers

$11-27-2020$

\title{
Overcoming Political Polarization: Federal Funding of Education Is the Key
}

\author{
Reuven S. Avi-Yonah \\ University of Michigan Law School, aviyonah@umich.edu
}

Follow this and additional works at: https://repository.law.umich.edu/law_econ_current

Digitalrt of the Education Commons, and the Law and Economics Commons

Commons

\section{Network}

Working Paper Citation

Avgr-Yonah, Reuven S., "Overcoming Political Polarization: Federal Funding of Education Is the Key" (2020). Law \& Economics Working Papers. 176.

https://repository.law.umich.edu/law_econ_current/176

This Article is brought to you for free and open access by University of Michigan Law School Scholarship Repository. It has been accepted for inclusion in Law \& Economics Working Papers by an authorized administrator of University of Michigan Law School Scholarship Repository. For more information, please contact mlaw.repository@umich.edu. 
OVERCOMING POLITICAL POLARIZATION:

FEDERAL FUNDING OF EDUCATION IS THE KEY

Reuven Avi-Yonah ${ }^{1}$

A republican form of government, without intelligence in the people, must be, on a vast scale, what a mad-house, without superintendent or keepers, would be on a small one

-Horace Mann

Does this picture look familiar? ${ }^{2}$

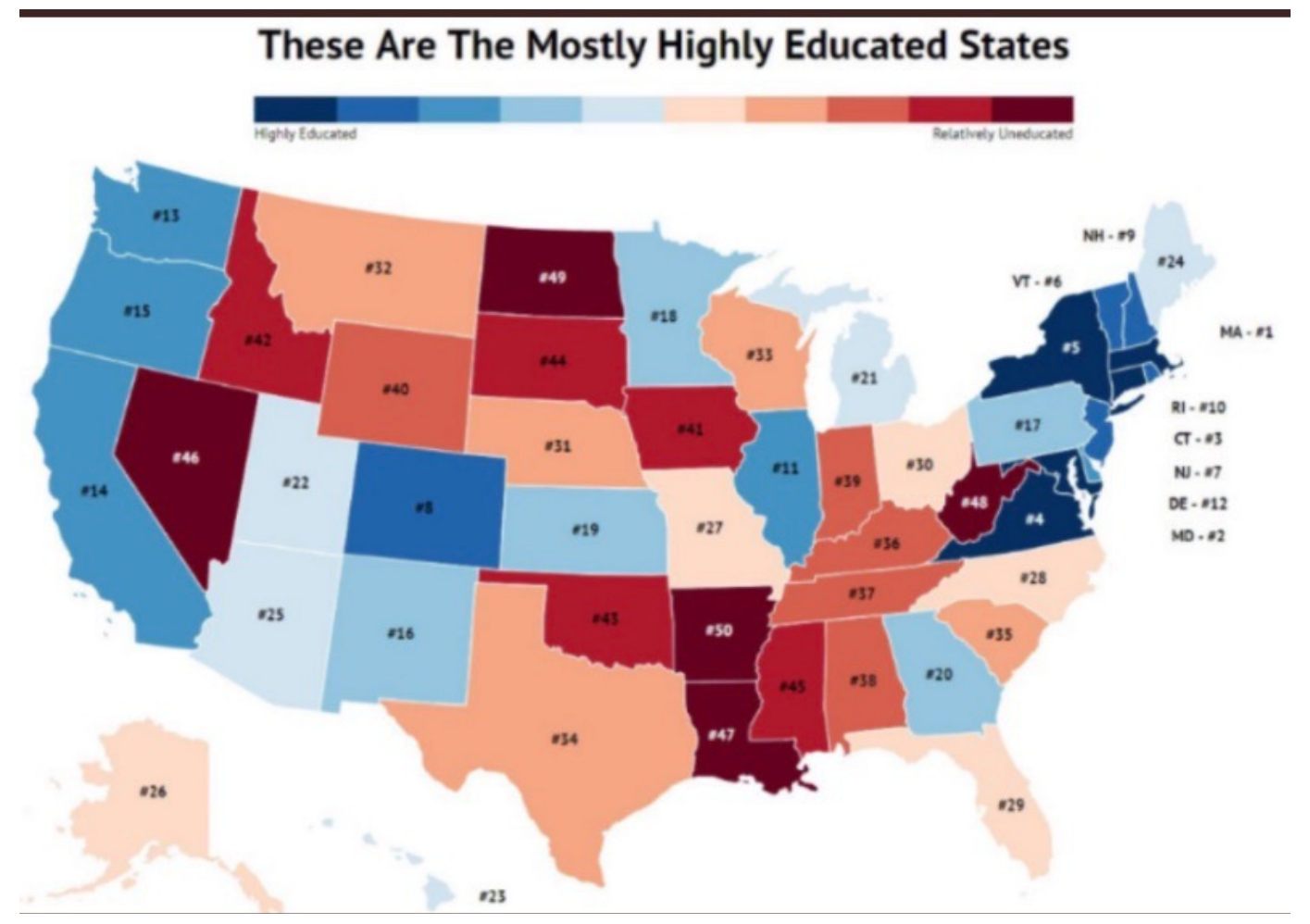

\footnotetext{
${ }^{1}$ Irwin I. Cohn Professor of Law, the University of Michigan. I would like to thank Kim Clausing for helpful comments.

${ }^{2}$ https://www.zippia.com/advice/most-highly-educated-states-in-america/
} 
If the captions were removed, the picture looks remarkably like the outcome of the 2020 presidential election. The blue states voted for Biden, the red for Trump. The exceptions are Kansas and Utah (blue states voting for Trump) and Wisconsin and Nevada (red states voting for Biden), but one cannot mistake the correlation in the other 46 states. Even Georgia, the big surprise of 2020, is correctly colored.

This suggests that the best way of overcoming political polarization in the US (the last two elections were both decided by fewer than 100,000 votes in WI, MI, PA (2016) and WI, AZ, GA (2020)) is to reduce disparities in education. But how can we do that?

The basic problem arises from the US system of funding K-12 education from property taxes. While the picture above refers to graduate education, it is K-12 education that determines both college admissions and college readiness, and college is in turn the prerequisite for graduate degrees. ${ }^{3}$

To illustrate the problem, consider one case study: the funding of public education in the City of Detroit (one of the poorest cities in the US) and its wealthy suburbs. ${ }^{4}$

As is common in the US, funding for public education in Michigan once relied entirely on local property tax revenues. Because of concerns about the inequality of property tax bases by school district and the wish to restrict property taxes, Michigan voters approved Proposal A in 1994, which used a $2 \%$ increase in the state sales tax to fund equalization payments, and limited the ability of richer districts to spend more than poorer ones. However, even though Proposal A contributed to reducing the disparity in funding between rich and poor districts, there are still major discrepancies because the initial funding differential is built into the system, resulting in per student funding in the Detroit suburbs (about $\$ 12,000$ per student) that is almost double that of Detroit (about $\$ 7000$ per student).

What can be done to remedy this situation? One possible solution is to create a unified school district that includes both Detroit and the suburbs, and to equalize the per student funding base across the unified district, as was done in NYC and LA. But given the history of racial animosity between Detroit and its suburbs, such a remedy is unlikely to be politically viable.

\footnotetext{
${ }^{3}$ The data above are based on the proportion of adults in each state that have at least a master's degree. Most of the population will never attain this level, but the key to overcoming polarization is to enable every child to maximize his or her potential, and that must begin in Pre-K and continue through $\mathrm{K}-12$ education and college. For a proposal to induce high level job creation in the relatively less educated regions of the country see Avi-Yonah, Reuven S. and Avi-Yonah, Orli and Fishbien, Nir and Xu, Haiyan, Bridging the Red-Blue Divide: A Proposal for U.S. Regional Tax Relief (July 2, 2019). U of Michigan Public Law Research Paper No. 620, Available at SSRN: https://ssrn.com/abstract=3249010 or http://dx.doi.org/10.2139/ssrn.3249010 ${ }^{4}$ For a fuller statement of the data see Avi-Yonah, Shera and Avi-Yonah, Reuven S., Leveling the Playing Field: The Case for an Education Value Added Tax (July 28, 2015). U of Michigan Public Law Research Paper No. 474, Available at SSRN: https://ssrn.com/abstract=2636728 or http://dx.doi.org/10.2139/ssrn.2636728
} 
A second option is to build on Proposal A and to use state support to completely equalize the per-student funding base. But even if such a revised Proposal A were not to founder on the same problems that we mentioned above, it is unlikely that the state of Michigan could raise adequate funds (about $\$ 6$ billion), because both the sales tax and the state income tax are vulnerable to "tax competition" problems that would preclude the state from raising the rates sufficiently.

Thus, the only viable solution is a federal solution. As President Nixon proposed in 1972, the United States should adopt an "Education Value Added Tax" (E- VAT) and use the revenues to equalize per student school funding across the country, as well as funding universal free public pre-K programs (such as the ones instituted by Mayor DeBlasio in NYC) and universal free public colleges for in-state residents (as used to be the case in California).

If each of the approximately 50 million $\mathrm{K}-12$ public school students in the US were funded at $\$ 10,000$, the federal government would need an additional $\$ 500$ billion in revenue each year.

This amount of money cannot easily be raised from the existing federal taxes. The federal government collects about $\$ 1.5$ trillion from the individual income tax and another $\$ 300$ billion from the corporate income tax (it also collects about $\$ 1$ trillion from payroll taxes, but those are in the public mind dedicated to social security). It is unrealistic to expect that we can raise the income taxes by several hundred billion dollars a year.

But there is another solution. Every other rich country (and about 120 less wealthy ones) relies on the Value Added Tax (VAT). The VAT is a proven revenue raiser and not subject to tax competition. A broad-based US VAT of $5 \%$ is expected to raise $\$ 500$ billion, which could entirely fund $\mathrm{K}-12$ education for every child in the US.

A VAT works because (a) it recruits the private sector to aid in its enforcement, (b) it is imposed on imports and on all domestic goods and services, and (c) it cannot be easily avoided except by emigration (even the "underground economy" which avoids the income tax is mostly covered, and since we have border controls we will avoid the problems the EU encounters with VAT fraud).

In order to make this happen, we need presidential leadership. We need a president who will address inequality of opportunity as a major problem and persuade his or her fellow Americans that addressing it is a major national challenge and that we should be willing to tax ourselves at $5 \%$ on all sales of goods and services (as well as imports) to finance a national attempt to provide the necessary preconditions for the pursuit of happiness to every American child. We believe that with such leadership, an Education VAT (E-VAT) whose revenues are segregated and used purely for education can be enacted, despite the general aversion to new taxes. 
What makes this solution politically feasible is that it envisages repealing all residential property taxes. ${ }^{5}$ The property tax is even more hated than the income tax, because people have to pay it out of pocket, and sometimes lose their homes if they are unable to pay. ${ }^{6}$ If people can be persuaded that federal funding need not mean federal control of education, and that locally elected school boards will still decide on the content of education with only a fixed amount per pupil provided by the feds and no strings attached, this can be a politically viable option.

In addition, if the political opportunity arises, we should also use the E-VAT to fund free public pre- $K$ and free public college (for in-state residents). Free pre- $K$ is essential because otherwise poor kids arrive at public K-12 too far behind to fully benefit from it. Free college is important because one of the main threats to equal opportunity is the crushing student debt burden on the middle class. An E-VAT would take care of all of those, not grow the government, and still be at the lower level of VATs around the world.

In 1972, President Nixon suggested replacing property taxes (which were very unpopular, especially in California where he came from) with a federal E-VAT. The problem was that in 1972 nobody in the US knew how a VAT works; it was a relatively new and untried tax, in operation only in the European Economic Community.

We now know how a VAT works: It is the largest and most successful tax in the world. If we want to address inequality of opportunity in America, an E-VAT is the best option. Such an EVAT could fulfill the educational vision of Horace Mann and avoid the US becoming a political mad house. It will bring the US back to where it belongs - a country that provides true equality of opportunity, not one that lags behind.

\footnotetext{
${ }^{5}$ Commercial property taxes should be retained to give local government a tax base for non-education expenses.

${ }^{6}$ Hence the political popularity of property tax limitation programs like Prop. 13 in CA, see

State Property Tax Freeze and Assessment Freeze Programs. In MI, the property tax assessment value must under Prop. A be limited to half of the home's real market value. But this can still lead to over-valuation when property values are based on historical data and real estate prices are declining, as happened in Detroit after 2008.
} 